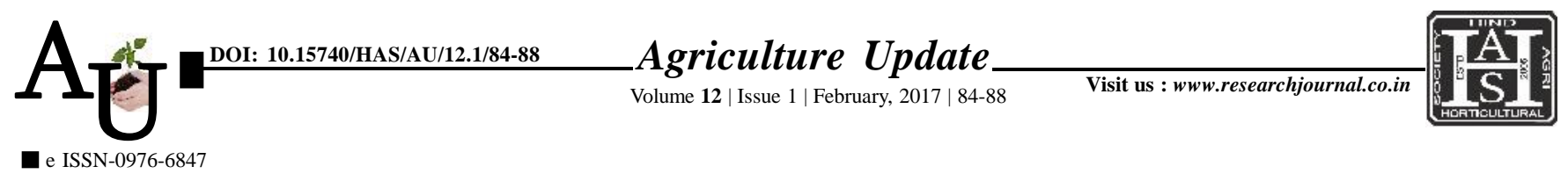

\title{
Research Article: Constraints faced by the banana growers in adoption of risk management practices in drip irrigated banana cultivation
}

$\square$ KRUNAL D. GULKARI, N. B. CHAUHAN AND V.T. ONIMA

Article Chronicle:

Received :

05.12.2016;

Revised :

25.12.2016;

Accepted :

03.01.2017

KEY WoRDS :

Adoption, Risk

management, Drip

irrigation, Banana,

Cultivation

Author for correspondence :

KRUNAL D. GULKARI

College of Agriculture, Anand Agricultural

University, VASO

(GUJARAT) INDIA

Email:krunalgulkari@

yahoo.in; kdgulkari@

gmail.com

See end of the article for

authors' affiliations
SUMMARY : The study to know constraints faced by the banana growers in adoption of risk management practices in drip irrigated banana cultivation was conducted on a random sample of 220 drip irrigated banana growers in Anand district of Gujarat state. The data were collected by personal contacts.Major economic problems faced by the banana growers in management of risk in drip irrigated banana cultivation were heavy cost of installation of drip irrigation system, high cost of fuel to use engines for irrigation and high cost of spare parts of drip irrigation system. As far as technological constraints faced by the banana growers were lack of sufficient electricity, problem of salty ground water and difficulty in interculturing operations. Non-availability of quality material of DIS with reasonable rates, lack of technical guidance from company agent in time and delay in sanction of loan and subsidy were the major administrative constraints faced by the banana growers. Whereas, in case of marketing related constraints faced by the banana growers were absences of support price during glut in the market, high cost of transportation and lack of timely information regarding demand and supply of the produce. Personal and socio-psychological constraints faced by the farmers in management of risk during drip irrigated banana cultivation were lack of knowledge about schedule of water soluble fertilizers application, lack of knowledge about use of fertilizers, liquid fertilizers, GR etc. and lack of knowledge about plant protection of banana crop. While, lack of knowledge about export procedure, lengthy procedures and formalities for export of produce and lack of knowledge about minimum residual level of chemical were the major export related constraints faced by the banana growers in drip irrigated banana cultivation.

How to cite this article : Gulkari, Krunal D., Chauhan, N.B. and Onima, V.T. (2017). Constraints faced by the banana growers in adoption of risk management practices in drip irrigated banana cultivation. Agric. Update, 12(1): 84-88; DOI : 10.15740/HAS/AU/12.1/84-88. 